JURNFL

INOVRSI EKRNOMI

\section{Self-congruence theory: Factors affecting brand loyalty in fast-moving consumer goods industry}

Nurul Aini ${ }^{1}$, Augusty Ferdinand ${ }^{2}$

Management Department, Postgraduate Program,

Universitas Diponegoro, Indonesia ${ }^{1,2}$

Received: 17-09-2021 | Revision: 28-09-2021 | Accepted: 12-10-2021

DOI: https://doi.org/10.22219/jiko.v7i01.18111

\begin{abstract}
This study aims to formulate a conceptual model for analyzing several variables on customer engagement and brand loyalty, especially in the fast-moving consumer goods (FMCG) industry. The self-congruence theory used in this study will go through the value of congruity, brand attractiveness, and customer-brand identification. The study uses structural equation modeling with samples of 105 respondents. The result is value congruence has a positive effect on brand attractiveness and customer brand identification. Customer engagement has a positive impact on customer brand identification. Brand attractiveness has a positive impact on customer brand identification and brand loyalty. Also, customer brand identification has a positive effect on brand loyalty.
\end{abstract}

Keywords: Brand loyalty, customer engagement, self-congruence theory

\footnotetext{
${ }^{1}$ nrula95@gmail.com
} 


\section{Introduction}

Research from Nielsen found a change in customer preferences in making purchasing decisions lately. The Nielsen Global Customer Loyalty Research Q1 2019 found that $38 \%$ of Indonesians like to try new brands, specifically for customers in the fruit juice category, $47 \%$ of customers indicated that they would still change the brand of fruit juice they would buy ${ }^{2}$. In the fruit juice and juice category, Buavita is the most popular fruit juice and juice drink brand in Indonesia based on the Top Brand Index from 2018 to 2020. Based on the 20182020 Top Brand Index data, Buavita always excels with 37.1\%, 43.3\%, and 31.6\%3. Furthermore, the Home Tester Club survey on May 5, 2019, with 373 respondents, showed Buavita to be the most chosen brand by customers based on considerations in terms of original and natural, taste does not contain artificial preservatives, choice of flavors, low sugar, and the best price. However, based on these data, only $8 \%$ of customers have loyalty to a fruit juice brand 4 .

Low brand loyalty can undoubtedly be a threat to business continuity. Brand loyalty is one way to increase market share and company sustainability in the industry (Yoo \& Bai, 2013) According to Chaudhuri \& Holbrook (2001), brand loyalty is critical to success and achievement marketing strategy. Therefore, many businesses compose various loyalty programs to acquire new customers and retain existing customers. Brand loyalty consists of a behavioral component and an attitude component (Jacoby \& Kyner, 1973). Behavioral loyalty refers to repeat purchases, while attitudinal loyalty refers to consumer attitudes towards a preferred brand (Cossío-Silva et al., 2016).

There are many ways to create and develop customer loyalty to a brand to survive. A significant way to trigger, build, or grow brand loyalty is through customer engagement (Islam et al., 2017). According to social exchange theory, customer engagement includes various things: reciprocal interactions between customers and brands (Hollebeek, 2011). According to Kumar \& Pansari, (2015), customer engagement can be observed from the existence of purchases and provide recommendations on brands, share brand experience, and improve brand products, especially in terms of quality through contribution to the brand community provide feedback on the brand.

Previous researchers found that customer engagement can affect brand loyalty. Customer engagement is a relationship between consumers with other consumers, companies, and certain brands that support increased brand loyalty (Brodie et al., 2011). A positive relationship with the brand and its followers can increase consumer loyalty. According to Dwivedi (2015), engagement has a

\footnotetext{
${ }^{2}$ See more at Insights - NielsenIQ

${ }^{3}$ See more at Top Brand Index With Complete Category | Top Brand Award (topbrand-award.com)

${ }^{4}$ See more at $\underline{\text { Home Tester Club }}$
} 
significant impact on loyalty intentions and can also increase consumers' value, quality, and satisfaction. Currently, customers engagement is a factor that drives brand loyalty (Harrigan et al., 2017).

From various existing marketing theories, this research uses a selfcongruity theory to describe how customer engagement can create brand loyalty because self-congruity can describe consumer behavior (Hosany, 2016). Through self-congruence, we can see whether consumers like a brand. Landon (1974) highlighted the role of self-concept in consumer behavior; research on consumer behavior has explained various constructs, including attitudes, preferences, choices, loyalty, and so on) in terms of the relationship between one's self-image and one's perceived image to a particular product or service. This idea became known as the theory of self-congruity. The self-congruence theory defines psychological processes and outcomes. Customers compare their perceptions of brand personality or image with their actual, ideal, social, and ideal social self-concept (Sirgy, 2018).

Studies related to the use of self-congruence theory are found in the hospitality sector (Sop \& Kozak, 2019), tourism (Chen et al., 2020; Huang et al., 2017) and the restaurant sector (Han et al., 2020). Based on our best knowledge, almost no research is known to simultaneously investigate self-congruence on the variables of customer engagement, value congruence, brand attractiveness, customer brand identification, and brand loyalty regarding the fast-moving consumer goods (FMCG) industry. Therefore, this study validates the selfcongruence theory in the FMCG or retail industry with particular reference to fruit juice packaged drinks consumers. The self-congruity theory used in this study will go through several mediating variables, namely value congruence, brand attractiveness, and customer-brand identification.

This study aims to formulate a conceptual model that can analyze several variables on customer engagement and brand loyalty and conduct empirical testing of other factors that affect brand loyalty. This study is expected to enrich the previous findings by Bergel et al. (2019), who have found the psychological process of how customer engagement affects brand loyalty; thus this research builds a new model for marketing in various business fields, especially for the FMCG industry.

\section{Method}

The population of this study is Buavita customers in all regions of Indonesia aged 17-35 years. The sampling technique used is a random sampling; the selected respondents are Buavita's Instagram followers. Purposive sampling is also done by contacting Buavita's followers on Instagram, assuming they are Buavita consumers who have bought Buavita at least two times as respondents who meet the requirements. The research was conducted from mid-March 2021 
to the end of August 2021. This study uses SEM with the consideration that SEM is an appropriate analytical tool used for multivariate analysis in social research that uses latent variables (variables that cannot be measured directly). We used an online questioner for collecting data through Google Forms to 245 people, of which 137 people filled in, but 29 of them were incomplete. They, therefore, could not be used in the study, so this study used 108 respondents and proceeded data by AMOS 22 software.

\section{Table 1. Indicators Variables}

\section{Variables} Indicators

Customer engagement is frequent 1 . Interact with brands through social media

interactions between customers 2 . Liked events organized by the brand

and brands that enhance 3. Have fun interacting with the brand

affective, cognitive, and 4. Want to know more about the brand

investment behavior towards the Sources: De Vries \& Carlson, (2014); Kaur et al., brand.

(2020); Li et al., (2020); Rather et al., (2018)

Source: Li et al., (2020)

Value congruence describes the 1 . Reflection of a healthy and active lifestyle

similarities between consumers' 2 . Someone who cares about health

personal values and perceived 3. Feel like a 'healthy food' customer

brand value.

4. Relevant to values and needs

Source: Edwards \& Cable, (2009) Sources: Baker et al., (2020); Confente et al., (2020); Rather, (2018)

Brand attractiveness is the extent 1 . One of the most interesting fruit juice brands in to which consumers have a good Indonesia

evaluation of brand 2. Interesting name

characteristics. 3. Quality fruit juice

Source: Ahearne et al., (2005) 4. Provides an interesting variety of flavors

Source: Baker et al., (2020)

Consumer brand identification is 1. Emotional attachment to Buavita

consumer perception of unity 2. Feeling embarrassed when the news in the

with the brand. media criticizes Buavita

Source: Stokburger-Sauer et al., 3. Feel happy when someone compliments

Buavita.

4. Feel the brand has personal meaning

Sources: Lin et al., (2019); Rather et al., (2018); So

et al., (2017)

Brand loyalty is consumers have 1. Recommend Buavita to someone

a positive attitude towards a 2. Repurchase Buavita

particular brand and tend to buy 3. Buy other Buavita products

this brand regularly

4. Be loyal to the Buavita in the future

Source: Fullerton, (2003)

Sources: (De Vries \& Carlson, (2014); Li et al., (2020); Lin et al., (2019) 
The measurement scale of the questionnaire in this study is a Likert Scale of 1 - 10, where a value of 1 means strongly disagree, and a value of 10 means strongly agree. Furthermore, this study uses two independents (exogenous) variables, namely customer engagement and value congruence, and three dependent (endogenous) variables, namely brand attractiveness, customer brand identification, and brand loyalty. The following is the definition of each research variable and the indicators used in this study, as seen in Table 1. Also, the research framework can see in Fig. 1.

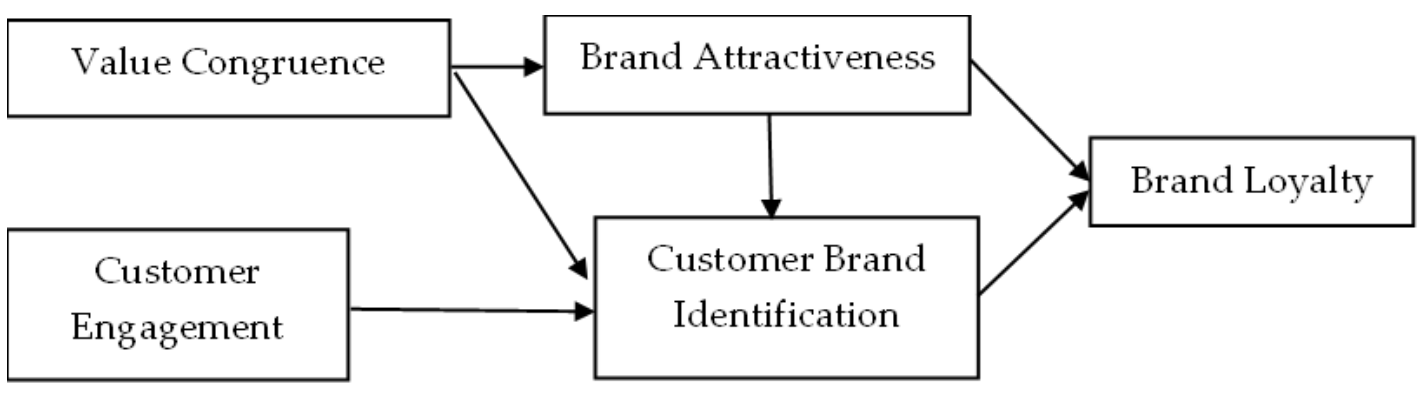

Figure 1. Research's framework

Hypothesis based on research's framework as see in Fig.1:

H1. Value congruence has a positive influence on brand attractiveness.

$\mathrm{H} 2$. Value congruence has a positive influence on customer brand identification.

H3. Customer engagement has a positive influence on customer brand identification.

H4. Brand attractiveness has a positive influence on customer brand identification.

H5. Brand attractiveness has a positive influence on brand loyalty.

H6. Customer Brand Identification has a positive influence on brand loyalty.

\section{Empirical Result}

The first step in performing a structural equation model (SEM) analysis is to create a measurement model to ensure the research data is valid and reliable. Based on the data processing results, standardized loading $(\lambda)$ obtained all variables measurement has a value above 0.5 , all AVEs have a value above 0.50 , and all CR has a value above 0.70 , that all variables are valid and reliable. The standardized loading $(\lambda), C R$, and AVE values of each variable are shown in Table 2.

The goodness of fitness in this measurement model is expected to meet the cut-off value based on Garson (2012). The outputs are shown in Table 3. Research hypothesis testing, this test was conducted to test the relationship between latent variables by looking at the value of c.r (Critical Ratio) > standard 
value 1.96 (significance level 5\%) in the regression weight table from the AMOS output. The outputs are shown in Table 4.

Table 2. Standardized Loading $(\lambda)$, AVE and CR

\begin{tabular}{|c|c|c|c|}
\hline Variables & $\begin{array}{c}\text { Std } \\
\text { Loading }\end{array}$ & $\begin{array}{l}\text { Construct } \\
\text { Realibility }\end{array}$ & $\begin{array}{c}\text { Average Variance } \\
\text { Extracted }\end{array}$ \\
\hline \multicolumn{4}{|c|}{ Customer Engagement } \\
\hline CE1 & 0.623 & \multirow{4}{*}{0.797} & \multirow{4}{*}{0.504} \\
\hline CE2 & 0.915 & & \\
\hline CE3 & 0.657 & & \\
\hline CE4 & 0.602 & & \\
\hline \multicolumn{4}{|c|}{ Value Congruence } \\
\hline VC1 & 0.782 & \multirow{4}{*}{0.853} & \multirow{4}{*}{0.594} \\
\hline VC2 & 0.705 & & \\
\hline VC3 & 0.810 & & \\
\hline VC4 & 0.782 & & \\
\hline \multicolumn{4}{|c|}{ Brand Attractiveness } \\
\hline BA1 & 0.492 & \multirow{4}{*}{0.798} & \multirow{4}{*}{0.506} \\
\hline BA2 & 0.830 & & \\
\hline BA3 & 0.794 & & \\
\hline BA4 & 0.682 & & \\
\hline \multicolumn{4}{|c|}{ Customer Brand } \\
\hline \multicolumn{4}{|c|}{ Identification } \\
\hline CBI1 & 0.578 & \multirow{4}{*}{0.804} & \multirow{4}{*}{0.511} \\
\hline CBI2 & 0.769 & & \\
\hline CBI3 & 0.811 & & \\
\hline CBI4 & 0.681 & & \\
\hline \multicolumn{4}{|c|}{ Brand Loyalty } \\
\hline BL1 & 0.781 & \multirow{4}{*}{0.80} & \multirow{4}{*}{0.507} \\
\hline BL2 & 0.627 & & \\
\hline BL3 & 0.715 & & \\
\hline BL4 & 0.719 & & \\
\hline
\end{tabular}

Table 3. Goodness of Fitness Output

\begin{tabular}{lccc}
\hline \multicolumn{1}{c}{ Metrics } & Cut of value & Output & Evaluation \\
\hline $\mathrm{X}^{2}$ - chi square & Small & 186.602 & Fit \\
Probability & $\geq 0,05$ & 0.770 & Fit \\
CMIN / DF & $\leq 2$ & 1.162 & Fit \\
RMSEA & $\leq 0.05$ & 0.039 & Fit \\
AGFI & $\geq 0.8$ & 0.823 & Fit \\
PCFI & $\geq 0.8$ & 0.829 & Fit \\
\hline
\end{tabular}

The hypothesis test between value congruence and brand attractiveness shows the results of CR 2.372, which means that hypothesis 1 is accepted where 
value congruence has a positive effect on brand attractiveness; this is by previous research fromElbedweihy et al., (2016). The hypothesis test between value congruence and customer brand identification shows the CR 2.176, which means that hypothesis 2 is accepted where value congruence has a positive effect on customer brand identification. This result is like research from Büyükdağ \& Kitapci, (2021) and Han et al., (2020). Then hypothesis test between customer engagement and customer brand identification shows the results of CR 2.610, which means that hypothesis 3 is accepted where customer engagement has a positive effect on customer brand identification as research by Fujita et al., (2020).

Table 4. Regression Weights

\begin{tabular}{|c|c|c|c|c|c|c|c|}
\hline \multicolumn{3}{|c|}{ Variables } & Estimate & S.E. & C.R. & $\mathbf{P}$ & Label \\
\hline $\begin{array}{l}\text { Brand } \\
\text { Attractiveness }\end{array}$ & $<--$ & $\begin{array}{l}\text { Value } \\
\text { Congruence }\end{array}$ & 0.156 & 0.066 & 2.372 & 0.018 & par_16 \\
\hline $\begin{array}{l}\text { Consumer Brand } \\
\text { Identification }\end{array}$ & $<--$ & $\begin{array}{l}\text { Value } \\
\text { Congruence }\end{array}$ & 0.190 & 0.087 & 2.176 & 0.030 & par_19 \\
\hline $\begin{array}{l}\text { Consumer Brand } \\
\text { Identification }\end{array}$ & $<--$ & $\begin{array}{l}\text { Brand } \\
\text { Attractiveness }\end{array}$ & 0.455 & 0.191 & 2.377 & 0.017 & par_20 \\
\hline $\begin{array}{l}\text { Consumer Brand } \\
\text { Identification }\end{array}$ & $<---$ & $\begin{array}{l}\text { Customer } \\
\text { Engagement }\end{array}$ & 0.339 & 0.130 & 2.610 & 0.009 & par_22 \\
\hline Brand Loyalty & $<---$ & $\begin{array}{l}\text { Brand } \\
\text { Attractiveness }\end{array}$ & 0.633 & 0.244 & 2.598 & 0.009 & par_17 \\
\hline Brand Loyalty & $<---$ & $\begin{array}{l}\text { Consumer Brand } \\
\text { Identification }\end{array}$ & 0.579 & 0.161 & 3.586 & $* * *$ & par_18 \\
\hline
\end{tabular}

Meanwhile, the hypothesis test between brand attractiveness and customer brand identification shows the results of CR 2.377, which means that hypothesis 4 is accepted where brand attractiveness has a positive effect on customer brand identification as research byThen hypothesis test between brand attractiveness and brand loyalty shows the results of 2.598, which means that hypothesis 5 is accepted where brand attractiveness has a positive effect on brand loyalty, as research from Elbedweihy et al., (2016). The last hypothesis test between customer brand identification and brand loyalty shows the results of CR 3.586, which means that hypothesis 6 is accepted where customer brand identification has a positive effect on brand loyalty as research by Rather et al., (2019) and Han et al., (2020).

\section{Conclusions}

This research attempts to bridge the research gap and answer the research problems contained in the introduction above. The problem of this research is how to create excellent customer engagement in the juice industry to increase 
brand loyalty. Based on the results of research carried out using the object of the Buavita, it can be seen that it has a direct or indirect effect.

The relationship between value congruence and brand loyalty can go through brand attractiveness. The brand should have compatibility and similarity in value with consumers' values so that this suitability will affect the attractiveness of the brand and make customers loyal to the brand. The relationship between value congruence and brand loyalty can also be through customer brand identification. A brand needs to be perceived in unity with consumers; if consumers feel identical to a brand, it will affect customer loyalty. The relationship between customer engagement and brand loyalty can go through customer brand identification; when there is an interaction between consumers and brands and consumers feel identical to the brand, consumer loyalty to the brand can increase. The relationship between brand attractiveness and brand loyalty can go through customer brand identification; when consumers have a good evaluation of brand characteristics, consumers will feel that consumer values can increase brand loyalty.

\section{References}

Ahearne, M., Bhattacharya, C. B., \& Gruen, T. (2005). Antecedents and consequences of customer-company identification: Expanding the role of relationship marketing. Journal of Applied Psychology, 90(3). https://doi.org/10.1037/0021-9010.90.3.574

Baker, T. L., Chari, S., Daryanto, A., Dzenkovska, J., Ifie, K., Lukas, B. A., \& Walsh, G. (2020). Discount venture brands: Self-congruity and perceived value-for-money? Journal of Business Research, 116, 412-419. https://doi.org/10.1016/j.jbusres.2019.07.026

Bergel, M., Frank, P., \& Brock, C. (2019). The role of customer engagement facets on the formation of attitude, loyalty and price perception. Journal of Services Marketing, 31(7), 890-903. https://doi.org/10.1108/JSM-01-2019-0024

Brodie, R. J., Hollebeek, L. D., Jurić, B., \& Ilić, A. (2011). Customer engagement: Conceptual domain, fundamental propositions, and implications for research. Journal of Service Research, 14(3). https://doi.org/10.1177/1094670511411703

Büyükdağ, N., \& Kitapci, O. (2021). Antecedents of consumer-brand identification in terms of belonging brands. Journal of Retailing and Consumer Services, 59. https://doi.org/10.1016/j.jretconser.2020.102420

Chaudhuri, A., \& Holbrook, M. B. (2001). The chain of effects from brand trust and brand affect to brand performance: The role of brand loyalty. Journal of Marketing, 65(2). https://doi.org/10.1509/jmkg.65.2.81.18255

Chen, R., Zhou, Z., Zhan, G., \& Zhou, N. (2020). The impact of destination brand authenticity and destination brand self-congruence on tourist 
loyalty: The mediating role of destination brand engagement. Journal of Destination Marketing and Management, 15(3688), 100402. https://doi.org/10.1016/j.jdmm.2019.100402

Confente, I., Scarpi, D., \& Russo, I. (2020). Marketing a new generation of bioplastics products for a circular economy: The role of green self-identity, self-congruity, and perceived value. Journal of Business Research, 112, 431439. https://doi.org/10.1016/j.jbusres.2019.10.030

Cossío-Silva, F. J., Revilla-Camacho, M. Á., Vega-Vázquez, M., \& PalaciosFlorencio, B. (2016). Value co-creation and customer loyalty. Journal of Business Research, 69(5). https://doi.org/10.1016/j.jbusres.2015.10.028

De Vries, N. J., \& Carlson, J. (2014). Examining the drivers and brand performance implications of customer engagement with brands in the social media environment. In Journal of Brand Management (Vol. 21, Issue 6, pp. 495-515). Palgrave Macmillan Ltd. https://doi.org/10.1057/bm.2014.18

Dwivedi, A. (2015). A higher-order model of consumer brand engagement and its impact on loyalty intentions. Journal of Retailing and Consumer Services, 24(C), 100-109. https://doi.org/10.1016/j.jretconser.2015.02.007

Edwards, J. R., \& Cable, D. M. (2009). The Value of Value Congruence. Journal of Applied Psychology, 94(3). https://doi.org/10.1037/a0014891

Elbedweihy, A. M., Jayawardhena, C., Elsharnouby, M. H., \& Elsharnouby, T. H. (2016). Customer relationship building: The role of brand attractiveness and consumer-brand identification. Journal of Business Research, 69(8), 2901-2910. https://doi.org/10.1016/j.jbusres.2015.12.059

Fujita, M., Harrigan, P., Soutar, G. N., Kumar Roy, S., \& Roy, R. (2020). Enhancing member-institution relationships through social media: The role of other-user engagement behavior and similarity perceptions. Journal of Business Research, 121, 642-654. https://doi.org/10.1016/j.jbusres.2020.07.050

Fullerton, G. (2003). When Does Commitment Lead to Loyalty? Journal of Service Research, 5(4). https://doi.org/10.1177/1094670503005004005

Garson, D. (2012). Structural Equation Modeling. Statistical Association Publishing Blue Book Series.Asheboro: Statistical Association Publishing.

Han, S. H., Ekinci, Y., Chen, C. H. S., \& Park, M. K. (2020). Antecedents and the mediating effect of customer-restaurant brand identification. Journal of Hospitality Marketing and Management, 29(2), 202-220. https://doi.org/10.1080/19368623.2019.1603129

Harrigan, P., Evers, U., Miles, M., \& Daly, T. (2017). Customer engagement with tourism social media brands. Tourism Management, 59, 597-609. https://doi.org/10.1016/j.tourman.2016.09.015 
Hollebeek, L. (2011). Exploring customer brand engagement: Definition and themes. In Journal of Strategic Marketing (Vol. 19, Issue 7). https://doi.org/10.1080/0965254X.2011.599493

Hosany, S. (2016). The Effects of Self-image Congruence, Tourists' Experiences and Satisfaction on Behavioral Intentions. Asia Pacific Journal of Business, 4, $1-13$.

Huang, Z. (Joy), Zhang, C., \& Hu, J. (2017). Destination brand personality and destination brand attachment-the involvement of self-congruence. Journal of Travel and Tourism Marketing, 34(9), 1198-1210. https://doi.org/10.1080/10548408.2017.1330171

Islam, J. U., Rahman, Z., \& Hollebeek, L. D. (2017). Personality factors as predictors of online consumer engagement: an empirical investigation. Marketing Intelligence and Planning, 35(4). https://doi.org/10.1108/MIP-102016-0193

Jacoby, J., \& Kyner, D. B. (1973). Brand Loyalty Vs. Repeat Purchasing Behavior. Journal of Marketing Research, 10(1). https://doi.org/10.1177/002224377301000101

Kaur, H., Paruthi, M., Islam, J. U., \& Hollebeek, L. D. (2020). The role of brand community identification and reward on consumer brand engagement and brand loyalty in virtual brand communities. Telematics and Informatics, 46. https://doi.org/10.1016/j.tele.2019.101321

Kumar, V., \& Pansari, A. (2015). jmr\%2E15\%2E0044. Journal of Marketing Research, 0-51.

Landon, Jr., E. L. (1974). Self Concept, Ideal Self Concept, and Consumer Purchase Intentions. Journal of Consumer Research, 1(2). https://doi.org/10.1086/208590

Li, M. W., Teng, H. Y., \& Chen, C. Y. (2020). Unlocking the customer engagement-brand loyalty relationship in tourism social media: The roles of brand attachment and customer trust. Journal of Hospitality and Tourism Management, 44(July), 184-192. https://doi.org/10.1016/j.jhtm.2020.06.015

Lin, C. W., Wang, K. Y., Chang, S. H., \& Lin, J. A. (2019). Investigating the development of brand loyalty in brand communities from a positive psychology perspective. Journal of Business Research, 99, 446-455. https://doi.org/10.1016/j.jbusres.2017.08.033

Rather, R. A. (2018). Investigating the Impact of Customer Brand Identification on Hospitality Brand Loyalty: A Social Identity Perspective. Journal of Hospitality Marketing and Management, 27(5), 487-513. https://doi.org/10.1080/19368623.2018.1404539

Rather, R. A., Hollebeek, L. D., \& Islam, J. U. (2019). Tourism-based customer engagement: the construct, antecedents, and consequences. Service 
Industries

Journal,

$39(7-8)$

$519-540$.

https://doi.org/10.1080/02642069.2019.1570154

Rather, R. A., Tehseen, S., \& Parrey, S. H. (2018). Promoting customer brand engagement and brand loyalty through customer brand identification and value congruity. Spanish Journal of Marketing - ESIC, 22(3), 321-341. https://doi.org/10.1108/SJME-06-2018-0030

Sirgy, M. J. (2018). Self-congruity theory in consumer behavior: A little history. Journal of Global Scholars of Marketing Science, 28(2). https://doi.org/10.1080/21639159.2018.1436981

So, K. K. F., King, C., Hudson, S., \& Meng, F. (2017). The missing link in building customer brand identification: The role of brand attractiveness. Tourism Management, 59, 640-651. https://doi.org/10.1016/j.tourman.2016.09.013

Sop, S. A., \& Kozak, N. (2019). Effects of brand personality, self-congruity and functional congruity on hotel brand loyalty. Journal of Hospitality Marketing and Management, 28(8), 926-956. https://doi.org/10.1080/19368623.2019.1577202

Stokburger-Sauer, N., Ratneshwar, S., \& Sen, S. (2012). Drivers of consumerbrand identification. International Journal of Research in Marketing, 29(4). https://doi.org/10.1016/j.ijresmar.2012.06.001 
